\title{
PENGEMBANGAN PALUDARIUM SEBAGAI MEDIA PEMBELAJARAN BIOLOGI POKOK BAHASAN EKOSISTEM DI SMA
}

\author{
Development of Paludarium as Biology Learning Media \\ on The Subject of Ecosytem at Senior High School.
}

Ratna Komala, Ade Suryanda, Diana Dia Lismana

Biologi / Pendidikan Biologi Fakultas MIPA Universitas Negeri Jakarta

Email: asuryanda@unj.ac.id

\begin{abstract}
Paludarium is one the art of landscape design in a container with visualizing terrestrial ecosystem, aquatic ecosystem, and air ecosystem, so looks like a real in nature. Paludarium can be potential as a media of learning ecosytem. The aims of this research was to develop paludarium as Biology learning media on the subject of ecosystem and know the feasibility of paludarium as learning media. The research was held at Senior High School 38 Jakarta with using research and development method. Analysis of potential and problems, paludarium design, validation design, paludarium revision, paludarium try out were the steps in the research. Paludarium received the average score was $84,2 \%$ that achieved good interpretation. The average value to limited field try out (36 students) of the test after using paludarium was 82.77. The average value to wide scale field try out (72 students) of the test after using paludarium was 83.54 . The mastery of classical learning to limited field try out after using paludarium was $97.2 \%$ and to wide scale field try out after using paludarium was $81.9 \%$. The result of this research showed that the paludarium could be utilized as one of Biology learning media on the subject of ecosytem at senior high school.
\end{abstract}

\section{Keywords : Ecosystem, learning media, paludarium, research and development}

\section{PENDAHULUAN}

Perkembangan ilmu pengetahuan sejalan dengan perkembangan kreativitas manusia. Kreativitas yang sedang berkembang saat ini salah satunya yaitu seni mendesain lanskap dalam wadah kaca, contohnya yaitu seni lanskap pada pembuatan paludarium. Paludarium merupakan salah satu seni desain lanskap dalam sebuah wadah (Arrium) dengan memvisualisasikan ekosistem darat, air, udara sehingga terlihat layaknya di alam nyata (Murhananto, 2003). Paludarium yang didalamnya tidak terlepas dari unsur alam maka terdapat kemungkinan paludarium dapat dikembangkan sebagai media pembelajaran ekosistem.

Proses pembelajaran materi ekosistem tidak terlepas dari sebuah media pendukung pembelajaran. Media memegang peranan penting untuk mencapai tujuan pembelajaran. Semakin banyak siswa menggunakan media belajar semakin banyak pula pikiran dan gagasan yang dimilikinya, atau semakin tinggi kemampuan kognitifnya (Arsyad, 2011).

Berdasarkan hasil wawancara yang dilakukan kepada guru Biologi kelas X di SMA Negeri 38 Jakarta, diketahui terdapat permasalahan yang terjadi pada proses pembelajaran ekosistem. Permasalahan yang terjadi salah satunya yaitu kurangnya media pendukung dalam proses pembelajaran ekosistem, sehingga hal ini berpengaruh 
terhadap ketuntasan belajar siswa. Idealnya pada proses pembelajaran ekosistem, siswa belajar secara langsung di lingkungan sekitarnya.

Keterbatasan ruang dan waktu dalam proses pembelajaran ekosistem menyebabkan siswa tidak dapat belajar secara maksimal di lingkungan sekitarnya. Pada pembelajaran ekosistem siswa masih terbatas pada penggunaan media akuarium sederhana, yang hanya menampilkan ekosistem dalam air (aquatic). Berdasar pada permasalahan yang telah dipaparkan, maka diperlukannya inovasi untuk mengembangkan suatu media pembelajaran ekosistem sehingga berpengaruh pula terhadap ketuntasan belajar siswa. Oleh karena itu maka dikembangkan Paludarium sebagai Media Pembelajaran Biologi Pokok Bahasan Ekosistem di SMA.

\section{METODE PENELITIAN}

Metode penelitian yang digunakan adalah pengembangan (Research and Development). Penelitian dan pengembangan yaitu proses yang digunakan untuk mengembangkan dan memvalidasi produk. Adapun langkah-langkah pengembangan paludarium mengacu pada penelitian pengembangan Borg \& Gall yang dimodifikasi dengan melibatkan 10 langkah utama, yaitu: (1) melakukan analisis potensi dan masalah (2) perencanaan, (3) desain paludarium (4) validasi ahli, (5) revisi paludarium berdasarkan saran ahli, (6) uji coba lapangan terbatas, (7) revisi paludarium berdasarkan saran uji coba lapangan terbatas, (8) uji lapangan skala luas, (9) revisi produk akhir, (10) produk akhir yaitu paludarium sebagai media pembelajaran biologi pokok bahasan ekosistem.

\section{HASIL DAN PEMBAHASAN}

Persentase hasil terendah pada uji validasi oleh ahli media yaitu $77 \%$ dengan interpretasi baik pada indikator tampilan paludarium. Hal ini dikarenakan saat penilaian, tampilan area depan pada wilayah daratan paludarium masih terlalu luas. Persentase hasil tertinggi yaitu $90 \%$ dengan interpretasi sangat baik pada indikator

bentuk fisik media dan bahan dasar yang digunakan untuk pembuatan media paludarium. Hal ini dikarenakan bentuk fisik sudah sesuai dengan bentuk secara umum dalam membuat paludarium serta bahan dasar yang digunakan sudah tepat dan aman. Secara keseluruhan penilaian paludarium oleh ahli media memperoleh skor rata-rata $83 \%$ dengan interpretasi baik.

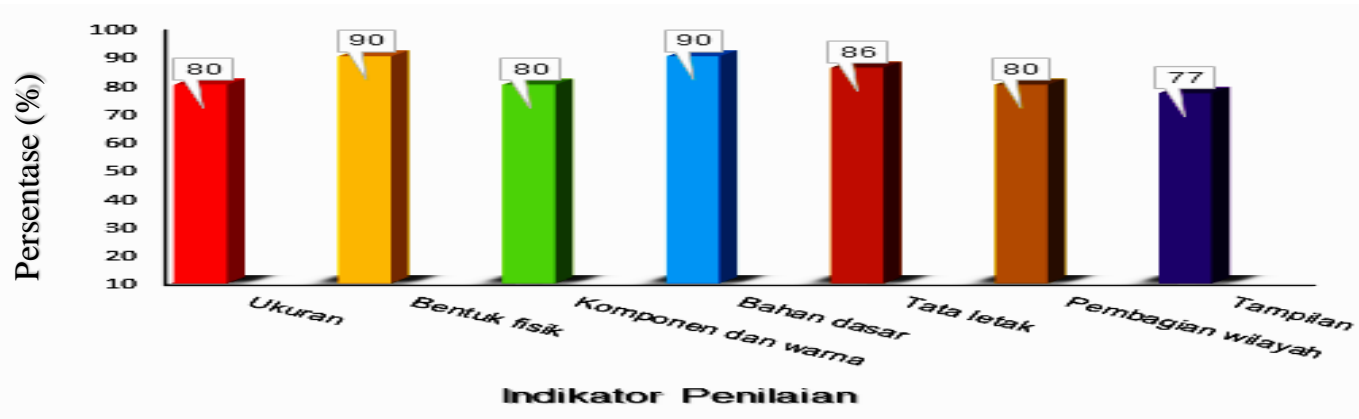

Gambar 1. Hasil uji validasi media paludarium oleh ahli media 
Persentase hasil terendah pada uji validasi oleh ahli materi yaitu $70 \%$ dengan interpretasi baik pada indikator pendukung materi pembelajaran. Hal ini dikarenakan paludarium belum dapat menampilkan seluruh materi ekosistem, salah satunya yaitu proses sukesi. Persentase hasil tertinggi yaitu 90\% dengan interpretasi sangat baik pada indikator kesesuaian materi yang divisualisasikan terhadap kompetensi inti (KI) dan kompetensi dasar (KD). Hal ini diartikan bahwa media yang dibuat telah sesuai dengan tujuan yang akan dicapai. Sesuai dengan pendapat Purnawati (2009), bahwa dalam pertimbangan memilih media perlu melihat ketepatan dengan tujuan pembelajaran artinya media yang dipilih atas dasar tujuan-tujuan instruksional yang telah ditetapkan. Secara keseluruhan validasi paludarium oleh ahli materi memperoleh persentase ratarata skor $80 \%$ dengan interpretasi baik.

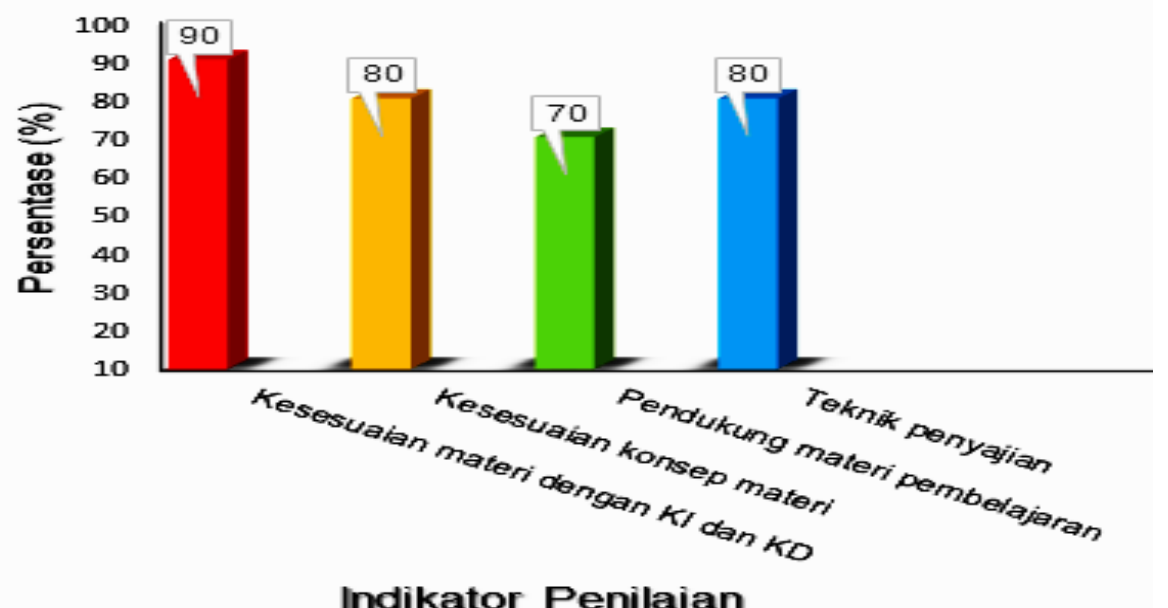

Gambar 2. Hasil uji validasi media paludarium oleh ahli materi

Hasil analisis terhadap saran dari uji validasi oleh ahli media dan materi digunakan untuk merevisi produk yang sebelumnya telah dikembangkan sebagai produk awal. Perbaikan dari segi media dan materi meliputi penyesuaian tata letak hewan yang didasarkan pada ukuran realita hewan tersebut, penambahan miniatur tumbuhan pada wilayah daratan, dan penambahan spesies tumbuhan darat maupun air.

Persentase hasil terendah pada uji coba paludarium oleh guru Biologi yaitu $80 \%$ dengan interpretasi baik pada indikator pendukung materi pembelajaran. Persentase hasil tertinggi yaitu 95\% dengan interpretasi sangat baik pada indikator media pembelajaran dapat memotivasi siswa. Guru Biologi melakukan uji coba penggunaan paludarium dengan cara mendemonstrasikan kepada siswa.

Hal tersebut dikarenakan paludarium termasuk media visual, sesuai dengan pendapat Smaldino (2005), bahwa penggunaan media visual dilakukan dengan cara memamerkannya (mendemonstrasikan) sehingga pesan dan informasi yang terdapat didalamnya dapat diamati dan dipelajari oleh siswa.

Menurut hasil dari uji coba yang telah dilakukan oleh guru Biologi, media paludarium sudah sangat menggambarkan ekosistem alamiah, sehingga proses belajar dan mengajar memenuhi tuntutan kurikulum 2013. Hal ini didukung oleh pendapat Daryanto (2010), bahwa materi pembelajaran yang terkandung di dalam media harus sesuai dengan kurikulum dan mengandung banyak manfaat. Secara keseluruhan 
penilaian paludarium oleh guru Biologi memperoleh rata-rata skor $89 \%$ dengan interpretasi baik.

Persentase hasil terendah pada uji coba lapangan terbatas yang dilakukan oleh 36 siswa yaitu $76 \%$ dengan interpretasi baik pada indikator pemahaman konsep. Persentase hasil tertinggi yaitu $86 \%$ dengan interpretasi baik pada indikator pendukung materi pembelajaran dan teknik penyajian media paludarium. Secara keseluruhan pada uji coba lapangan terbatas, penilaian paludarium memperoleh persentase rata-rata skor 83\% dengan interpretasi baik.

Persentase hasil terendah pada uji lapangan skala luas yang dilakukan oleh 72 siswa yaitu $82 \%$ dengan interpretasi baik pada indikator pemahaman konsep. Persentase hasil tertinggi yaitu $88 \%$ dengan interpretasi baik pada indikator pendukung materi pembelajaran dan teknik penyajian media paludarium. Secara keseluruhan pada uji lapangan skala luas, penilaian paludarium memperoleh skor $86 \%$ dengan interpretasi baik.

Pada uji coba lapangan terbatas maupun uji coba lapangan skala luas dilakukan tes latihan pemahaman sebanyak 4 soal uraian yang dikerjakan sesudah menggunakan media paludarium. Rata-rata hasil belajar uji pemahaman siswa pada uji coba skala terbatas dengan menggunakan paludarium sebagai media pembelajaran yaitu 82,77. Rata-rata hasil belajar uji pemahaman siswa pada uji coba skala luas dengan menggunakan paludarium sebagai media pembelajaran yaitu 83,54. Penggunaan media paludarium pada pembelajaran ekosistem dapat membantu mencapai ketuntasan belajar klasikal, hal ini dibuktikan dari hasil uji lapangan terbatas dan skala luas. Berdasarkan hasil pengolahan nilai tes pemahaman siswa pada uji lapangan terbatas diketahui siswa yang mencapai kriteria ketuntasan minimal $(7,5)$ sebanyak 35 siswa dari 36 siswa. Dengan demikian pada uji lapangan terbatas memperoleh kriteria ketuntasan belajar klasikal adalah 97,2\%.

Berdasarkan hasil pengolahan nilai tes pemahaman siswa pada uji lapangan skala luas diketahui siswa yang mencapai kriteria ketuntasan minimal $(7,5)$ sebanyak 59 siswa dari 72 siswa. Dengan demikian pada uji lapangan skala luas memperoleh kriteria ketuntasan belajar klasikal adalah 81,9\%. Sesuai dengan ketentuan Permendikbud Nomor 66 Tahun 2013 tentang Standar Penilaian yaitu ketuntasan klasikal dicapai jika daya serap klasikal mencapai minimal 75\%, maka hasil tes pemahaman siswa pada uji lapangan terbatas maupun skala luas sudah mencapai ketuntasan belajar klasikal yang dibuktikan dengan persentase ketuntasan belajar klasikal keduanya sudah melebihi $75 \%$.

Berdasarkan data dan deskripsi tersebut maka diketahui paludarium sebagai media pembelajaran Biologi pokok bahasan ekosistem dapat meningkatan hasil belajar siswa. Hal ini sesuai dengan pendapat Arsyad (2011) yang mengemukakan bahwa media pembelajaran dapat memperjelas penyajian pesan dan informasi sehingga dapat memperlancar serta meningkatkan proses dan hasil belajar.

Produk akhir dari pengembangan paludarium merupakan paludarium yang telah direvisi berdasarkan saran dari para ahli serta pengguna paludarium. Lingkup materi ekosistem yang dapat divisualisasikan yaitu satuan makhluk hidup, komponen ekosistem, rantai makanan, jaring-jaring makanan, interaksi dalam ekosistem, dan daur air. Produk akhir dari pengembangan media paludarium dapat dilihat pada Gambar 3 sebagai berikut: 


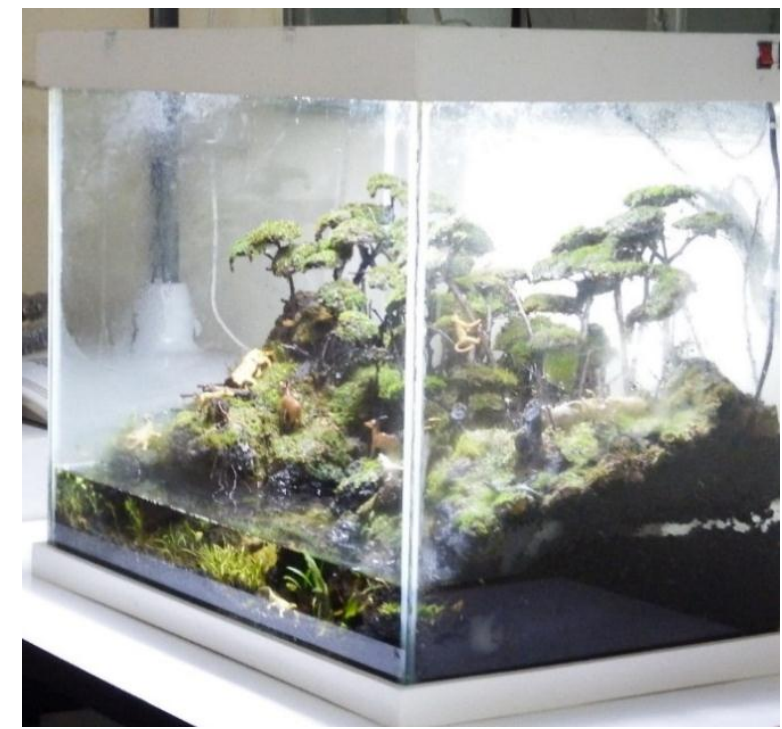

Gambar 3. Media Paludarium (Sumber: Dok.Pribadi)

\section{KESIMPULAN}

Hasil uji kelayakan media paludarium sebagai secara keseluruhan memperoleh persentase rata-rata skor $84,2 \%$ dengan interpretasi nilai baik, sehingga paludarium memenuhi kelayakan sebagai media pembelajaran Biologi pokok bahasan ekosistem.

\section{DAFTAR PUSTAKA}

Arsyad, A. (2011). Media Pembelajaran. Jakarta: PT. Raja Grafindo Persada Borg and Gall. (1983). Educational Research, An Introduction. New York and London. Longman Inc

BSNP. (2014). Panduan Penyusunan Kurikulum. Jakarta: Departemen Pendidikan Nasional

Daryanto. (2010). Media Pembelajaran. Yogyakarta: Gava Media

Gay, L.R. (1991). Educational Evaluation and Measurement: Competencies for Analysis and Application. Second edition. New York: Macmillan Publishing Compan Indriana, D. (2011). Ragam Alat Bantu Media Pengajaran. Jogjakarta: Diva Press Mindoro. (1994). in Collier's Encyclopedia, Vol.II. New York: Harper Murhananto. (2003). Paludarium Paduan Gemericik Air Terjun dan Eksotika akuarium. Jakarta: Agromedia

Odum, E. (1993). Dasar- Dasar Ekologi (Edisi ke-3). Yogyakarta: Gajah Mada University Press

Peraturan Menteri Pendidikan Dan Kebudayaan. (2013). Standar isi - Standar Proses Kompetensi Inti - Kompetensi Dasar Mata Pelajaran Biologi SMA. Jakarta: Depdikbud Sadiman, S.A. (2010). Media Pendidikan. Jakarta: PT. Raja Grafindo Persada Sumarna, C. (2006). Hubungan Penggunaan Alat Peraga dalam Pembelajaran Ilmu Pengetahuan Sosial dengan Potensi Belajar Siswa. Cirebon: Tarbiyah.

Rahayu, K. (2012). Dasar-Dasar Statistik Pendidikan. Bandung: CV. Pustaka setia 